\author{
Dr Małgorzata DWORAKOWSKA \\ Kolegium Ekonomiczno-Społeczne, Szkoła Główna Handlowa w Warszawie \\ e-mail: mdwora@sgh.waw.pl \\ ORCID: 0000-0003-4949-1616
}

DOI: $10.15290 /$ oes.2018.03.93.05

\title{
DOCHODY BUDŻETOWE JEDNOSTEK SAMORZĄDU TERYTORIALNEGO Z PERSPEKTYWY ABSORPCJI FUNDUSZY UNIJNYCH
}

\begin{abstract}
Streszczenie
Cel - Celem artykułu jest przedstawienie specyfiki dochodów budżetowych jednostek samorządu terytorialnego $\mathrm{w}$ Polsce $\mathrm{w}$ kontekście pozyskiwania funduszy unijnych przez te podmioty w latach 2007-2016.

Metodologia badania - Aby osiagnnąć wyznaczony cel użyto różnych metod badawczych. W procedurze badawczej wykorzystano metody badań niereaktywnych, zastosowano metodę analizy dokumentów urzędowych i metodę historyczno-porównawczą.

Sytuację finansową jednostek samorządu terytorialnego można opisywać w kilku aspektach, wśród których wyodrębnia się analizę dochodów budżetowych, badanie wydatków budżetowych, charakterystykę wyniku budżetowego i niejednokrotnie towarzysząca mu problematykę długu komunalnego. Dochody budżetowe kształtują możliwości wydatkowe jednostek samorządu terytorialnego. Szczególną rolę odgrywają dochody własne, które powiększone o dochody uzupełniające, czyli subwencję ogólną i dotacje ogółem, składają się na całość dochodów budżetowych. Poprzez dysponowanie odpowiednimi zasobami finansowymi, jednostki samorządu terytorialnego są w stanie realizować przypisane im zadania publiczne. Dzięki dostępności dla Polski funduszy unijnych, dochody budżetowe jednostek samorządu terytorialnego stały się ważną determinantą warunkująca możliwości absorpcji środków finansowych z budżetu Unii Europejskiej.

Wyniki - Dochody budżetowe to ważny element systemu finansów jednostek samorządu terytorialnego. Wpływają one na zdolność jednostek samorządu terytorialnego do realizacji zadań publicznych, ponieważ umożliwiają ich finansowanie. Przeprowadzone analizy wskazują specyfikę dochodów budżetowych jednostek samorządu terytorialnego i ich szczególną rolę z perspektywy absorpcji środków finansowych z budżetu Unii Europejskiej. Zebrane dane świadczą o zaangażowaniu jednostek samorządu terytorialnego w Polsce w latach 2007-2016 w absorpcję funduszy unijnych.
\end{abstract}

Słowa kluczowe: dochody budżetowe, fundusze unijne, jednostki samorządu terytorialnego

\section{BUDGET REVENUE OF LOCAL GOVERNMENT UNITS FROM THE PERSPECTIVE OF THE ABSORPTION OF EU FUNDS}

\section{Summary}

Goal - The article aims to present the specificity of budget revenue of local government units in Poland in the context of obtaining EU funds by these entities in the years 2007-2016. 
Research methodology - In order to achieve the assumed purpose, different research methods were used. The research procedure involved non-reactive research methods, the method of analysis of official documents as well as the historical and comparative method.

The financial situation of local government units can be described trough various aspects, including e.q. the analysis of budget revenue, the examination of budget expenditure, the characteristics of the budget result and the frequently related issues of municipal debt. Budget revenue shapes the expenditure possibilities of local government units. A special role is played by their own revenue, which is increased by supplementary revenue, i.e. the general subsidy and total allocations, that make up the entire budget revenue. Due to having appropriate financial resources, local government units are able to carry out the public tasks assigned to them. Thanks to the availability of EU funds for Poland, the budget revenue of local government units have become an important determinant conditioning the absorption of financial resources from the European Union budget.

Score - Budget revenue is an important element of the financial system of local government units. It affects the ability of local government units to carry out their public tasks because it enables their financing. The analysis shows the specificity of budget revenue of local government units and its important role from the perspective of absorption of financial resources from the European Union budget. The collected data proves the involvement of local government units in Poland in the years 2007-2016 in the absorption of EU funds.

Keywords: budget revenue, EU funds, local government units

JEL classification: H71, H72, H79

\section{Wstęp}

Działalność każdej jednostki samorządu terytorialnego łączy się z zaspokajaniem zbiorowych potrzeb mieszkańców, co odbywa się poprzez realizację zadań publicznych. Ich wykonywanie wymaga dysponowania przez jednostki samorządu terytorialnego adekwatnymi środkami finansowymi w stosunku do wyznaczonych zadań. Źródłem informacji o środkach finansowych, którymi gospodaruje jednostka samorządu terytorialnego jest jej budżet, czyli roczny plan, w którym uwzględnione są sumy dochodów oraz wydatków, a także przychodów oraz rozchodów. Ten plan jest uchwalany na dany rok budżetowy, który w Polsce jest tożsamy z rokiem kalendarzowym. Zaznaczyć należy, że różnie jest traktowana strona dochodowa i wydatkowa budżetu. Świadczy o tym fakt, że kwoty dochodów i przychodów jednostki samorządu terytorialnego są ujmowane jako prognozy, a kwoty wydatków i rozchodów stanowią nieprzekraczalny limit. Strona dochodowa kształtuje więc możliwości wydatkowe jednostek samorządu terytorialnego.

Potrzeby wydatkowe budżetów jednostek samorządu terytorialnego nie zawsze sa zaspokajane tylko poprzez własne środki budżetowe. W związku z tym, pojawia się konieczność pozyskiwania pieniędzy ze źródeł o charakterze zewnętrznym. Mają one kluczowe znaczenie dla zwiększenia sprawności oraz skuteczności działania jednostek samorządu terytorialnego na rzecz gromadzenia środków, służących finansowaniu wydatków budżetowych, zwłaszcza przeznaczonych na inwestycje. Jednym z najważniejszych zewnętrznych źródeł finansowania jednostek samorządu terytorialnego sa środki finansowe z funduszy strukturalnych oraz z Funduszu Spój- 
ności (FS) ${ }^{1}$. Jednostki samorządu terytorialnego uzyskały do nich dostęp po wstapieniu Polski do Unii Europejskiej (UE). Otrzymanie wsparcia z tych funduszy nie następuje automatycznie, a jednostka samorządu terytorialnego musi zabezpieczyć między innymi wkład własny, którego sfinansowaniu w całości lub w części służą dochody budżetowe. W pierwszych latach po akcesji szczególne znaczenie miały środki unijne o charakterze bezzwrotnym. Obecnie akcent jest kładziony na korzystanie z funduszy unijnych w formule zwrotnej, co służy wielokrotnemu wykorzystaniu pieniędzy na różne przedsięwzięcia.

Celem artykułu jest przedstawienie specyfiki dochodów budżetowych jednostek samorządu terytorialnego w Polsce w kontekście pozyskiwania funduszy unijnych przez te podmioty w latach 2007-2016. Ze względu na ograniczone ramy niniejszego artykułu przedmiotem analizy nie jest problematyka związana $z$ limitami zadłużenia jednostek samorządu terytorialnego, które ograniczają możliwości korzystania ze środków finansowych o charakterze dłużnym.

\section{Dochody budżetowe w gospodarce finansowej jednostek samorządu terytorialnego}

Finanse jednostek samorządu terytorialnego sa podstawą realizacji zadań publicznych przez te podmioty i decydują o warunkach rozwoju gospodarczego w ujęciu lokalnym i regionalnym [Wojciechowski, 2012, s. 234]. Działalność jednostek samorządu terytorialnego wymaga oddania do dyspozycji ich organów zasobów środków publicznych, które umożliwiaja zorganizowanie, dostarczanie oraz sfinansowanie zarówno usług publicznych, jak i społecznych, za które odpowiedzialność ponoszą władze samorządowe. W istotę oraz zasady funkcjonowania jednostek samorządu terytorialnego godzi wyposażenie organów samorządu terytorialnego tylko w ustalony katalog uprawnień i kompetencji, ale bez zadbania o odpowiednie źródła dochodów publicznych [Patrzałek, 2010, s. 132]. Aby samorząd terytorialny mógł w sposób aktywny odgrywać rolę w tworzeniu warunków życia oraz gospodarowania społeczności lokalnych, to musi zostać wyposażony w stosowne zasoby finansowe [Kogut-Jaworska, 2008, s. 22]. Sprawne i skuteczne wykonywanie zadań publicznych wymaga zaopatrzenia jednostek samorządu terytorialnego w wydajne i stabilne źródła dochodów budżetowych.

Dochody budżetowe jednostki samorządu terytorialnego są źródłem informacji o ogólnym obrazie jej zasobności i kształtują kierunki wydatkowania środków finan-

1 Często stosowanym przez jednostki samorządu terytorialnego zewnętrznym źródłem finansowania są przychody budżetowe zwrotne, wśród których najczęściej wykorzystywane są kredyty oraz pożyczki zaciagane przez jednostkę samorządu terytorialnego, a mniejszą popularnością cieszy się pozyskiwanie środków finansowych ze sprzedaży wyemitowanych papierów wartościowych. Użycie zwrotnych źródeł finansowania wymaga uwzględnienia w budżetach kolejnych lat pieniędzy potrzebnych na pokrycie zaciagniętych zobowiązań. Innym zewnętrznym źródłem finansowania jednostek samorządu terytorialnego jest partnerstwo publiczno-prywatne, ale jego wdrażania i możliwości stosowania władze samorządowe dopiero się uczą. 
sowych [Filipiak, Dylewski, Gorzałczyńska-Koczkodaj, 2011, s. 45]. Zaznaczyć należy, że w obowiązujących przepisach prawa nie zostało wyjaśnione pojęcie dochodów jednostek samorządu terytorialnego [Dolnicki, 2012, s. 321]. W prowadzeniu gospodarki i polityki finansowej jednostek samorządu terytorialnego istotne znaczenie maja źródła dochodów budżetowych i ich struktura. Zakres dochodów jednostek samorządu terytorialnego może być kształtowany przez system [Jastrzębska, 2012, s. 106-107]:

- $\quad$ scentralizowanych źródeł finansowania, który łączy się z metodą koncentracji wpływów w budżecie państwa, z którego są przydzielane środki pieniężne jednostkom samorządu terytorialnego, powoduje to poważne uzależnienie jednostek samorządu terytorialnego od państwa w zakresie ich zadań i kompetencji;

- zdecentralizowanych źródeł finansowania, czyli powiązany z metodą dekoncentracji wpływów pomiędzy budżety jednostek samorządu terytorialnego i budżet państwa, wymaga powiązania wydatków danej jednostki samorządu terytorialnego z jej możliwościami finansowymi i utrudnia wyrównywanie dysproporcji w rozwoju między tymi podmiotami;

- mieszany, inaczej pośredni, bazujący zarówno na metodzie koncentracji, jak i dekoncentracji wpływów.

Najważniejszym źródłem finansowania działalności jednostek samorządu terytorialnego i kluczowym instrumentem realizacji polityki władz samorządowych jest budżet [Sierak, 2013, s. 151]. Jego istotną częścią są dochody budżetowe. Źródła tych dochodów są określone w przepisach prawa, a ich podział pomiędzy administrację rządową oraz administrację samorządową powinien uwzględnić w szczególności zasadę adekwatności, inaczej odpowiedniości, dochodów przekazywanych jednostkom samorządu terytorialnego w stosunku do przypadających im zadań. Ta zasada jest spełniona wtedy, gdy przekazane dochody budżetowe umożliwiaja jednostkom samorządu terytorialnego sfinansowanie w całości wydatków niezbędnych na zrealizowanie przydzielonych zadań. Podkreślić należy, że urzeczywistnienie tej zasady jest utrudnione w szczególności za sprawą różnic między jednostkami samorządu terytorialnego w zakresie poziomu wyposażenia w infrastrukturę społeczną oraz infrastrukturę techniczna, zróżnicowanego tempa rozwoju gospodarczego i nierównomiernego rozkładu źródeł dochodów własnych [Kańduła, 2017, s. 44-45].

Dochody jednostek samorządu terytorialnego w latach 2007-2016 systematycznie zwiększały się (tabela 1). W ciagu analizowanych dziesięciu lat wzrosły ze 131,4 mld zł do 213,7 mld zł. Corocznie obserwowany wzrost dochodów wystapił w gminach i miastach na prawach powiatu. Dochody tych jednostek samorządu terytorialnego w ostatnim badanym roku były ponad półtorakrotnie wyższe niż w 2007 r. W powiatach i województwach nie w każdym roku dochody zwiększały się w relacji do roku wcześniejszego. Zestawienie danych o dochodach tych jednostek samorządu terytorialnego za 2016 r. z tymi z pierwszego roku poddanego analizie pozwala również zauważyć wzrost dochodów, który był jednak mniej niż półtorakrotny. $\mathrm{Na}$ całkowita kwotę dochodów budżetowych składają się wpływy pochodzące z różnych źródeł. 
TABELA 1

\section{Dochody ogółem jednostek samorządu terytorialnego (kwoty wykonane, w mln zł)}

\begin{tabular}{|l|c|c|c|c|c|c|c|c|c|c|}
\hline Wyszczególnienie & $\mathbf{2 0 0 7}$ & $\mathbf{2 0 0 8}$ & $\mathbf{2 0 0 9}$ & $\mathbf{2 0 1 0}$ & $\mathbf{2 0 1 1}$ & $\mathbf{2 0 1 2}$ & $\mathbf{2 0 1 3}$ & $\mathbf{2 0 1 4}$ & $\mathbf{2 0 1 5}$ & $\mathbf{2 0 1 6}$ \\
\hline $\begin{array}{l}\text { Jednostki samorzadu } \\
\text { terytorialnego ogółem, } \\
\text { w tym: }\end{array}$ & 131378 & 142583 & 154842 & 162797 & 171309 & 177413 & 183458 & 194337 & 199019 & 213669 \\
\hline gminy & 57004 & 62318 & 64882 & 72311 & 75831 & 78407 & 80043 & 84549 & 87667 & 101795 \\
\hline $\begin{array}{l}\text { miasta na prawach } \\
\text { powiatu }\end{array}$ & 46874 & 49452 & 50328 & 53886 & 56860 & 61247 & 64217 & 68260 & 70560 & 74420 \\
\hline powiaty & 16155 & 18147 & 20084 & 22496 & 23552 & 22523 & 23078 & 23783 & 23681 & 23948 \\
\hline województwa & 11345 & 12666 & 19548 & 14104 & 15067 & 15236 & 16121 & 17746 & 17110 & 13506 \\
\hline
\end{tabular}

Źródło: opracowanie własne na podstawie [Bank Danych Lokalnych].

Dochody budżetowe mogą być różnorodnie klasyfikowane. Wyodrębnia się podział dochodów budżetowych jednostek samorządu terytorialnego na dochody obligatoryjne i fakultatywne [Ustawa 2003, art. 3]. W skład dochodów obligatoryjnych wchodzą: dochody własne, subwencja ogólna oraz dotacje celowe z budżetu państwa. Dochodami fakultatywnymi są natomiast: środki pochodzące ze źródeł zagranicznych, niepodlegające zwrotowi, środki pochodzące z budżetu UE i inne środki określone w przepisach odrębnych od ustawy o dochodach jednostek samorządu terytorialnego. To oznacza, że katalog źródeł dochodów o charakterze fakultatywnym ma charakter otwarty.

Inny podział dochodów budżetowych jednostek samorządu terytorialnego obejmuje wyodrębnienie dochodów majątkowych oraz dochodów bieżących [Ustawa 2009, art. 235 ust. 2-3]. W myśl tej klasyfikacji dochodami majątkowymi są: dotacje i środki przeznaczone na inwestycje, dochody ze sprzedaży majątku oraz dochody z tytułu przekształcenia prawa użytkowania wieczystego w prawo własności. Za dochody bieżące uznaje się natomiast pozostałe dochody budżetowe. W gospodarce finansowej jednostek samorządu terytorialnego dochody bieżące są kilkakrotnie wyższe niż dochody majątkowe. Taka ich relacja wynika z obciążenia jednostek samorządu terytorialnego znaczną liczbą zadań o charakterze bieżącym.

Kolejna klasyfikacja dochodów budżetowych jednostek samorząa terytorialnego pozwala charakteryzować je z perspektywy źródeł ich pochodzenia. Zgodnie z tym podziałem wyodrębnia się dochody własne i uzupełniające. W każdej jednostce samorządu terytorialnego bazę finansową powinny stanowić dochody własne, co oznacza, że ich udział w całkowitej strukturze dochodów powinien kształtować się na jak najwyższym poziomie. W polskich rozwiązaniach prawnych kategoria dochodów własnych została scharakteryzowana przez określenie źródeł finansowania do niej zaliczonych. Dochodami własnymi jednostek samorządu terytorialnego są więc: wpływy z podatków, wpływy z opłat, dochody z majątku, udziały w podatkach centralnych i pozostałe dochody. Wśród dochodów własnych kluczowe znaczenie mają dochody z podatków i opłat, ponieważ władze samorządowe mogą oddziaływać na wysokość wpływów budżetowych z tych źródeł, dzięki moż- 
liwości kształtowania wysokości stawek podatkowych i opłat². Wśród dochodów z majątku wyodrębnia się przede wszystkim środki pochodzące z tytułu umów sprzedaży, dzierżawy bądź najmu nieruchomości oraz dywidendy ze sprzedaży rzeczy, praw lub majątku. Kontrowersje budzi zaliczanie udziałów w podatkach centralnych (PIT i CIT) do dochodów własnych, ponieważ w zakresie kształtowania tego źródła dochodów jednostki samorządu terytorialnego nie dysponuja żadnym władztwem. To źródło dochodów własnych stanowi formę transferu pieniędzy do budżetu jednostki samorządu terytorialnego i przez swoją specyfikę jest bliższe dochodom uzupełniającym niż dochodom własnym.

Dochody uzupełniające występują pod postacią subwencji ogólnej i dotacji. Sąźródłem finansowania jednostek samorządu terytorialnego przez transfer środków finansowych do budżetu jednostki samorządu terytorialnego. Przekazywane w ten sposób pieniądze moga pochodzić z budżetu państwa, z budżetów innych jednostek samorządu terytorialnego oraz z pozostałych funduszy publicznych. Subwencja ogólna dla jednostek samorządu terytorialnego obejmuje trzy części: wyrównawczą oświatową i równoważąca (regionalna). Jest przyznawana na podstawie obiektywnych przesłanek. Drugim rodzajem dochodów uzupełniających są dotacje, które przyznaje się jednostkom samorządu terytorialnego z użyciem uznaniowych kryteriów. To oznacza, że dotacje mogą być instrumentem oddziaływania państwa na jednostki samorządu terytorialnego, w celu wykonywania określonych działań. Celowość dotacji oznacza ścisłe wskazanie kierunków wydatkowania pieniędzy uzyskanych z tego źródła, co blokuje swobodę realizacji przedsięwzięć przez jednostki samorządu terytorialnego.

Uwzględniając specyfikę poszczególnych źródeł dochodów budżetowych jednostek samorządu terytorialnego stwierdzić należy, że kluczowym źródłem ich finansowania powinny być dochody własne. Dopełnienie dochodów własnych powinna stanowić subwencja ogólna. Najmniej znaczące w strukturze dochodów powinny być dotacje.

Analiza faktycznej sytuacji finansowej jednostek samorządu terytorialnego wykazuje poważne zróżnicowanie udziału dochodów własnych w strukturze dochodów budżetowych [por. Bank Danych Lokalnych]. Wśród jednostek samorządu terytorialnego wyróżniają się miasta na prawach powiatu, w których udział dochodów własnych w dochodach ogółem stanowi ponad połowę dochodów budżetowych. Podobna sytuację obserwuje się w gminach, gdzie dochody własne są najistotniejszym źródłem finansowania, ale ich udział w strukturze dochodów ogółem stanowi mniej niż połowę dochodów budżetowych. W powiatach natomiast subwencja

2 Pamiętać należy, że wśród jednostek samorządu terytorialnego istnieje zróżnicowanie dochodów własnych. Najszerszy katalog dochodów własnych mają gminy. Powiaty oraz województwa nie uzyskują wpływów z tytułu samodzielnych dochodów podatkowych, ponieważ żaden podatek nie stanowi w całości źródła finansowania tych podmiotów. Województwa nie dysponują również możliwością pozyskiwania środków finansowych z tytułu opłat wpłacanych do budżetu tego samorządu, gdyż żadna opłata nie jest źródłem ich dochodów własnych. W związku z taką sytuacją, zestaw źródeł dochodów własnych województw jest najwęższy. Miasta na prawach powiatu uzyskuja dochody własne należne gminie i powiatowi. 
ogólna jest najważniejszym źródłem dochodów budżetowych, a powinny nim być dochody własne. Gospodarka finansowa powiatów bazuje więc na dochodach uzupełniających. Subwencja ogólna dostarcza zwykle najmniejszą część wpływów budżetów województw. Najlepszą strukturę dochodów mają zatem miasta na prawach powiatu.

Zastosowanie podziału dochodów budżetowych jednostek samorządu terytorialnego na dochody własne, subwencję ogólną i dotacje pozwala najpełniej analizować problematykę dochodów budżetowych tych podmiotów z perspektywy absorpcji funduszy unijnych.

\section{Fundusze unijne jako źródło finansowania wydatków budżetowych jednostek samorządu terytorialnego}

Kwota dostępnych dla Polski funduszy europejskich różniła się zależnie od okresu programowania. Najmniej pieniędzy było w latach 2004-2006 (12,8 mld euro), czyli bezpośrednio po wstapieniu Polski w struktury UE. W perspektywie finansowej 2007-2013 Polska miała do dyspozycji ponad pięciokrotnie więcej środków w porównaniu z latami 2004-2006 i było to 67,3 mld euro. W obecnym okresie programowania pula dostępnych środków finansowych jest jeszcze większa i wynosi 82,5 mld euro. Z tej kwoty około 40\% środków jest przeznaczone na finansowanie potrzeb wydatkowych jednostek samorządu terytorialnego. To oznacza, że jednostki samorządu terytorialnego to poważny beneficjent funduszy unijnych. Środki finansowe pozyskiwane przez jednostki samorządu terytorialnego z budżetu UE pozwalają na wykonywanie różnorodnych przedsięwzięć, głównie inwestycyjnych.

Fundusze unijne umożliwiaja realizację wielu inwestycji w jednostkach samorząqu terytorialnego, które przekładają się na polepszenie warunków życia mieszkańców i działania podmiotów gospodarczych. Środki finansowe z funduszy unijnych sa przekazywane jednostkom samorządu terytorialnego przez 16 Regionalnych Programów Operacyjnych, które służą poprawie konkurencyjności regionów oraz promocji zrównoważonego rozwoju. Wsparcia finansowego dla jednostek samorządu terytorialnego dostarczają również krajowe programy operacyjne, w obecnej perspektywie finansowej: Program Operacyjny Infrastruktura i Środowisko, Program Operacyjny Wiedza Edukacja Rozwój, Program Operacyjny Polska Cyfrowa, Program Operacyjny Polska Wschodnia.

Zdolności absorpcyjne funduszy unijnych przez jednostki samorządu terytorialnego są mocno związane z sytuacją finansową tych podmiotów, przede wszystkim w zakresie dochodów. Kluczowym źródłem dochodów budżetowych jednostek samorządu terytorialnego z perspektywy starania się o środki unijne są dochody własne.

Fundusze unijne, o które ubiegają się jednostki samorządu terytorialnego, są za każdym razem przyznawane na realizację konkretnego zadania ustalonego w umowie i w myśl zasady dodatkowości. UE nie finansuje przedsięwzięć w całości i zawsze jest wymagany wkład własny beneficjenta. Maksymalny poziom dofinan- 
sowania z funduszy strukturalnych jest zróżnicowany i zależy od poziomu rozwoju regionu. W perspektywie finansowej 2014-2020 dla Mazowsza jako regionu lepiej rozwiniętego wynosi $80 \%$ wydatków kwalifikowanych projektu (merytorycznie uzasadnionych), a dla pozostałych regionów Polski jest utrzymany na poziomie 85\%, czyli takim, jaki obowiązywał w latach 2007-2013 dla wszystkich regionów Polski. Zarówno w obecnej, jak i minionych perspektywach finansowych maksymalne dofinansowanie z FS wynosi $85 \%$. W sytuacji, gdy jednostka samorządu terytorialnego jako beneficjent ubiega się o maksymalne dofinansowanie, to i tak musi pokryć pozostałe wydatki kwalifikowane (20\% lub 15\%) i całość wydatków niekwalifikowanych. Dofinansowanie z UE przyznawane jest wyłącznie najlepiej przygotowanym projektom. Jednostki samorządu terytorialnego chcąc zwiększyć swoje szanse na uzyskanie dofinansowania z UE niejednokrotnie ubiegają się o dofinansowanie niższe niż maksymalne. Wówczas z innych źródeł muszą zapewnić niezbędne środki finansowe potrzebne na wykonanie przedsięwzięcia w całości.

Wymagany od beneficjenta wkład własny często opiewa na znaczne sumy pieniędzy, co oznacza, że ich zgromadzenie w budżecie jednostki samorządu terytorialnego może być utrudnione. Brak możliwości zebrania wkładu własnego jest poważnym ograniczeniem w staraniach o pozyskanie funduszy unijnych w systemie bezzwrotnym. W obecnym okresie programowania kładzie się akcent na sprawne i skuteczne korzystanie przez jednostki samorządu terytorialnego $z$ instrumentów inżynierii finansowej, które pozwalają pozyskać finansowanie unijne w systemie zwrotnym. Taki system finansowania przedsięwzięć umożliwia wielokrotne wykorzystanie pieniędzy, co ma na celu zwiększenie liczby realizowanych inwestycji, ale wymaga większego zaangażowania finansowego ze strony jednostek samorządu terytorialnego.

Zdarzają się sytuacje, że dochody budżetowe jednostek samorządu terytorialnego nie wystarczają na realizację wydatków budżetowych, a co za tym idzie, sfinansowanie całego wkładu własnego z dochodów budżetowych jest niemożliwe. Odwołując się do specyfiki dochodów jednostek samorządu terytorialnego warto zaznaczyć, że dochody własne są najbardziej wskazanym budżetowym źródłem finansowania wkładu własnego beneficjenta, o ile wystarczy na ten cel pieniędzy z tego źródła. Realizacji inwestycji dofinansowanych z funduszy unijnych może towarzyszyć zaciąganie zobowiązań dłużnych na zapewnienie wkładu własnego beneficjenta. Takie rozwiązanie umożliwia pozyskanie wsparcia z budżetu UE, ale jednocześnie wymaga w przyszłości spłacenia, co będzie pochłaniać część środków budżetowych kolejnych lat [por. Alińska, Dworakowska, 2015, s. 246-249].

Trudności z zebraniem środków finansowych na wkład własny dotyczą szczególnie drogich przedsięwzięć. W takiej sytuacji wkład własny jednostki samorządu terytorialnego będzie opiewać na znaczne sumy środków finansowych. W konsekwencji oznacza to, że jego zgromadzenie może okazać się dla jednostki samorządu terytorialnego wyzwaniem przekraczającym możliwości budżetowe. Prognozowany łączny wkład własny jednostek samorządu terytorialnego w latach 2014-2020, który będzie niezbędny do uzyskania współfinansowania projektów ze środków unijnych wyniesie aż 60,62 mld zł, a łączne środki UE przewidziane w tym okresie dla jedno- 
stek samorządu terytorialnego to $107,2 \mathrm{mld}$ zł [Sierak i in., 2013, s. 9]. To wskazuje, jak znaczne jest zapotrzebowanie jednostek samorządu terytorialnego na środki finansowe.

Środki finansowe przekazane jednostkom samorządu terytorialnego w związku z realizacją programów i projektów unijnych w latach 2007-2016 wahały się od 6,6 mld zł w 2007 r. do 7,2 mld zł w 2016 r., przy czym największe były w 2014 r. i wyniosły 18,2 mld zł (tabela 2). Najwyższy ich poziom odnotowano w województwach w 2009 r. (9,6 mld zł), w gminach w 2011 r. (6,5 mld zl), w miastach na prawach powiatu w 2014 r. (5,5 mld zł), a w powiatach w 2010 r. (2,1 mld zł). Zestawiając dane z 2016 r. z danymi z roku poprzedniego widać poważny spadek (około 2-3-krotny) środków finansowych otrzymanych przez jednostki samorządu terytorialnego w związku z realizacją programów i projektów unijnych.

TABELA 2

\section{Środki finansowe przekazane jednostkom samorządu terytorialnego w związku z realizacją programów i projektów unijnych (kwoty wykonane, w mln zł)}

\begin{tabular}{|l|c|c|c|c|c|c|c|c|c|c|}
\hline Wyszczególnienie & $\mathbf{2 0 0 7}$ & $\mathbf{2 0 0 8}$ & $\mathbf{2 0 0 9}$ & $\mathbf{2 0 1 0}$ & $\mathbf{2 0 1 1}$ & $\mathbf{2 0 1 2}$ & $\mathbf{2 0 1 3}$ & $\mathbf{2 0 1 4}$ & $\mathbf{2 0 1 5}$ & $\mathbf{2 0 1 6}$ \\
\hline $\begin{array}{l}\text { Jednostki samorządu } \\
\text { terytorialnego } \\
\text { ogółem, w tym: }\end{array}$ & 6622 & 5448 & 14509 & 13793 & 16345 & 17078 & 16013 & 18169 & 17201 & 7218 \\
\hline gminy & 1702 & 1200 & 2016 & 5069 & 6459 & 5873 & 4360 & 4695 & 4853 & 1431 \\
\hline $\begin{array}{l}\text { miasta na prawach } \\
\text { powiatu }\end{array}$ & 2239 & 1737 & 2002 & 2946 & 3592 & 5524 & 5000 & 5531 & 5209 & 2746 \\
\hline powiaty & 678 & 323 & 927 & 2093 & 1843 & 1341 & 1258 & 1342 & 1066 & 418 \\
\hline województwa & 2003 & 2187 & 9564 & 3686 & 4452 & 4340 & 5395 & 6601 & 6074 & 2623 \\
\hline
\end{tabular}

Źródło: opracowanie własne na podstawie [Bank Danych Lokalnych].

Dane obrazujące udział środków finansowych przekazanych jednostkom samorządu terytorialnego w związku z realizacją programów i projektów unijnych w dochodach ogółem w latach 2007-2016 świadczą o tym, że był on zróżnicowany (tabela 3). Kształtował się w województwach pomiędzy 17,7\% w 2007 r. a 19,4\% w 2016 r. (najwyższy 48,9\% w 2009 r.), w powiatach od 4,2\% w 2007 r. do 1,7\% w 2016 r. (największy 9,3\% w 2010 r.), w miastach na prawach powiatu między 4,8\% w 2007 r. a 3,7\% w 2016 r. (najwyższy 9,0\% w 2012 r.), a w gminach od 3,0\% w 2007 r. do 1,4\% w 2016 r. (największy 8,5\% w 2011 r.). Na tle wszystkich obserwacji wyróżniały się województwa z udziałem kilkakrotnie wyższym niż inne jednostki samorządu terytorialnego. 
TABELA 3

Udział środków finansowych przekazanych jednostkom samorządu terytorialnego $\mathrm{w}$ związku $\mathrm{z}$ realizacją programów i projektów unijnych w dochodach ogółem (w \%)

\begin{tabular}{|l|c|c|c|c|c|c|c|c|c|c|}
\hline \multicolumn{1}{|c|}{ Wyszczególnienie } & $\mathbf{2 0 0 7}$ & $\mathbf{2 0 0 8}$ & $\mathbf{2 0 0 9}$ & $\mathbf{2 0 1 0}$ & $\mathbf{2 0 1 1}$ & $\mathbf{2 0 1 2}$ & $\mathbf{2 0 1 3}$ & $\mathbf{2 0 1 4}$ & $\mathbf{2 0 1 5}$ & $\mathbf{2 0 1 6}$ \\
\hline $\begin{array}{l}\text { Jednostki samorządu } \\
\text { terytorialnego ogółem, } \\
\text { w tym: }\end{array}$ & 5,0 & 3,8 & 9,4 & 8,5 & 9,5 & 9,6 & 8,7 & 9,3 & 8,6 & 3,4 \\
\hline gminy & 3,0 & 1,9 & 3,1 & 7,0 & 8,5 & 7,5 & 5,4 & 5,6 & 5,5 & 1,4 \\
\hline miasta na prawach powiatu & 4,8 & 3,5 & 4,0 & 5,5 & 6,3 & 9,0 & 7,8 & 8,1 & 7,4 & 3,7 \\
\hline powiaty & 4,2 & 1,8 & 4,6 & 9,3 & 7,8 & 6,0 & 5,5 & 5,6 & 4,5 & 1,7 \\
\hline województwa & 17,7 & 17,3 & 48,9 & 26,1 & 29,5 & 28,5 & 33,5 & 37,2 & 35,5 & 19,4 \\
\hline
\end{tabular}

Źródło: opracowanie własne na podstawie [Bank Danych Lokalnych].

System dochodów jednostek samorządu terytorialnego charakteryzuje się cechami, które oddziałują na zdolności absorpcyjne funduszy unijnych przez te podmioty:

- niestabilność rozwiazzań prawnych regulujących działalność jednostek samorządu terytorialnego, w szczególności ich system dochodów - czynniki prawne w zasadniczy sposób oddziałują na strukturę dochodów jednostek samorządu terytorialnego i ich wielkość [Por. Bień, 2017, s. 47];

- $\quad$ system dochodów oparty na licznych źródłach finansowania mających ograniczony potencjał fiskalny i przydatność [Zioło, 2016, s. 34];

- niska wydajność fiskalna podatków i opłat lokalnych w gminach [Poniatowicz, 2016, s. 12-13];

- zawężony katalog dochodów własnych powiatów i województw, w którym brakuje wpływów z tytułu samodzielnych dochodów podatkowych, a w przypadku województw również wpływów z tytułu opłat;

- $\quad$ wysoki stopień zależności dochodów budżetowych jednostek samorządu terytorialnego od dochodów będących formą transferu pieniędzy z budżetu państwa;

- $\quad$ system finansowania części równoważącej (regionalnej) subwencji ogólnej, budzący zastrzeżenia jednostek samorządu terytorialnego, które są zobligowane przekazywać część zrealizowanych dochodów własnych na rzecz biedniejszych samorządów;

- $\quad$ wymagający zmian system finansowania części oświatowej subwencji ogólnej;

- wrażliwość systemu dochodów jednostek samorządu terytorialnego na wahania koniunktury gospodarczej - wpływ kryzysu, który odbił się zmniejszeniem niektórych wpływów budżetowych uzyskiwanych w ramach dochodów własnych i pogorszeniem struktury dochodów budżetowych jednostek samorządu terytorialnego;

- nakładanie na jednostki samorządu terytorialnego nowych zadań publicznych do realizacji bez zapewnienia niezbędnych środków finansowych 
potrzebnych na ich sfinansowanie, co powoduje niedobory pieniędzy w budżetach samorządów.

Wskazane cechy systemu dochodów jednostek samorządu terytorialnego obejmują najważniejsze kwestie, a wymieniony zestaw wyróżników ma charakter otwarty.

\section{Podsumowanie}

Dochody budżetowe jednostek samorządu terytorialnego stanowią ważny element systemu ich finansów. Oddziałują one na zdolność jednostek samorządu terytorialnego do wykonywania zadań publicznych, gdyż umożliwiają ich finansowanie. Spośród ogółu dochodów na szczególną uwagę zasługują dochody własne, które służą wzmocnieniu zaplecza finansowego jednostek samorządu terytorialnego. Dochody własne sa jednak ograniczone i nie pozwalają na sfinansowanie wszystkich przedsięwzięć. W związku z tym konieczne jest korzystanie przez jednostki samorządu terytorialnego z zewnętrznych źródeł finansowania.

Szczególnie polecane źródło dofinansowania stanowią fundusze unijne przeznaczone na daną perspektywę finansową. Dają one szanse na poprawę wyposażenia jednostek samorządu terytorialnego $\mathrm{w}$ infrastrukturę i tym samym przyśpieszenie ich rozwoju. Jednak wymagany od beneficjenta wkład własny może być trudny do zgromadzenia i stanowić ograniczenie w staraniach o pozyskanie funduszy unijnych. Możliwości absorpcyjne środków finansowych z budżetu UE są ściśle związane ze stanem finansów jednostek samorządu terytorialnego, zwłaszcza dochodów. Najważniejszym źródłem dochodów budżetowych jednostek samorządu terytorialnego z punktu widzenia starania się o środki unijne są dochody własne.

Zebrane i przeanalizowane dane świadczą o zaangażowaniu jednostek samorządu terytorialnego w Polsce w latach 2007-2016 w absorpcję środków finansowych z budżetu UE. Dokonane analizy pozwoliły wskazać specyfikę dochodów budżetowych jednostek samorządu terytorialnego oraz ich szczególne znaczenie z perspektywy absorpcji funduszy unijnych.

\section{Literatura}

Alińska A., Dworakowska M., 2015, Finanse jednostek samorzqdu terytorialnego, [w:] Wspótczesne finanse publične, Alińska A., Woźniak B. (red.), Difin, Warszawa.

Bank Danych Lokalnych, https://bdl.stat.gov.pl/BDL/dane/podgrup/temat [data wejścia: 11.04.2018].

Bień W., 2017, Ocena kondycji finansowej gmin wojewódz̨twa małopolskiego w latach $2007-$ 2016, „Studia Ekonomiczne”, nr 345.

Dolnicki B., 2012, Samorz̨qd terytorialny, Wolters Kluwer, Warszawa.

Filipiak B., Dylewski M., Gorzałczyńska-Koczkodaj M., 2011, Analiza finansowa budìetón jednostek samorzadu terytorialnego, Municipium, Warszawa. 
Jastrzębska M., 2012, Finanse jednostek samorzadu terytorialnego, Wolters Kluwer, Warszawa.

Kańduła S., 2017, Mechaniżmy ayrónnania fiskalnego: studium empiryczne gmin w Polsce w latach 2004-2014, Wydawnictwo Uniwersytetu Ekonomicznego w Poznaniu, Poznań.

Kogut-Jaworska M., 2008, System finansowania džałalności JST, [w:] Bankowo-finansowa obstuga jednostek samorzadu terytorialnego, Filipiak B., Flejterski S. (red.), CeDeWu, Warszawa.

Patrzałek L., 2010, Finanse samorzadu terytorialnego, Wydawnictwo Uniwersytetu Ekonomicznego we Wrocławiu, Wrocław.

Poniatowicz M., 2016, Stabilność finansowa jednostek samorzadu terytorialnego w aspekcie nowej perspektywy finansowej Unii Europejskiej $i$ zmian w systemie dochodów samorzadonych, „Ekonomiczne Problemy Usług”, nr 125, DOI: 10.18276/epu.2016.125-01.

Sierak J., 2013, Gospodarka finansowa jednostek samorzadu terytorialnego, [w:] Gospodarka i finanse samorzadu terytorialnego, Maśloch G., Sierak J. (red.), Oficyna Wydawnicza SGH, Warszawa.

Sierak J., Bitner M., Gałązka A., Górniak R., 2013, Oszacowanie środków nię̧bednych do zapewnienia krajowego wkładu publicznego do projektón realizowanych w ramach średniookresonych ram finansonych 2014-2020, Ministerstwo Rozwoju Regionalnego, Warszawa.

Ustawa z dnia 13 listopada 2003 r. o dochodach jednostek samorządu terytorialnego, tekst jednolity: Dz. U. 2017 poz. 1453 z późn. zm.

Ustawa z dnia 27 sierpnia 2009 r. o finansach publicznych, tekst jednolity: Dz. U. 2017 poz. 2077 z późn. zm.

Wojciechowski E., 2012, Zarzadzanie w samorzadzie terytorialnym, Difin, Warszawa.

Zioło M., 2016, Specyfika funkcionowania jednostek samorzadu terytorialnego a popyt na ustugi finansowe, [w:] Wspótpraca jednostek samorzadu terytorialnego z. instytucjami finansowymi: uwarunkowania - procesy - decyzje, Filipiak B.Z., Zioło M. (red.), Difin, Warszawa. 